\title{
Fear Turns into Violence: A Study of Richard Wright's (Select) Works
}

\author{
Dr. S. D. Sindkhedkar \\ Professor in English, PSGVP Mandal's S. I. Patil Arts, G. B. Patel Scie. \& \\ S.T.K.V.S. Comm. College, Shahada (M.S.) \\ $\&$ \\ A. D. Akhade \\ Assist. Professor in English, G.T. Patil College, Nandurbar(M.S.) \\ arunda1982@gmail.com \\ Mob: 9518763383
}

\begin{abstract}
Wright depicts his characters, especially, the protagonists, in a way that turns into violent being from their fearful state. A human being can be suppressed in an extension. One fears of death. So, the black youth tries to survive in fear, but when they found themselves facing the death, and no better way than violence, they react in that way. Some of the fictional characters of Wright are of this type. They kill in fear; and, after killing, repent in fear, knowing that they have to face the revengeful violence from the side of the killed one.
\end{abstract}

Keywords: Black youth, fear and violence.

\section{Introduction}

The researcher takes the characters from Richard Wright's works to study their nature how they turn into violence under the circumstances when they cannot find a better way than the violence. The protagonists are taken to illustrate the statement from the select works of Wright- Native Son, Lawd Today and Big Boy Leaves Home.

In Native Son, Bigger is conscious of self-respect but he fears about the system. He knows well the taboos of the white society. He keeps himself as per the expectation of white society. But an accident happens to him when he gets a job in a rich white family. He has been given a job of driver. While returning to home, Mr. Dalton's daughter, Mary drinks so much that she is unable to walk herself to her room. Bigger holds her in his hands and takes to her room. At the time, Mrs. Dalton comes there enquiring about Mary. Bigger fears that if he is caught in Mary's room he might be punished under a false crime. He fears that Mrs. Dalton can feel his presence there, though she is blind. Mary tries to get up and respond to her mother's call, but Bigger fears that he would be exposed there if Mrs. Dalton comes close to them. In his extreme fear, he feels the urge to stop Mary from speaking and rising from her bed. He puts the corner of a pillow to her mouth. As Mrs. Dalton moves ahead, though slowly, Bigger's body is tightened in an extreme fear. Now he is not little conscious of what is happening to Mary. His mind is fully occupied with fear only as Wright describes: 
'Mary's fingernails tore at his hands and he caught the pillow and covered her entire face with it, firmly. Mary's body surged upward and he pushed downward upon the pillow with all of his weight, determined that she must not move or make any sound that would betray him.' (Native, 117).

Bigger has no intention of killing her. He does not even realize that she is struggling to save her life. He only intends that her sound and movement should not cause Mrs. Dalton find him in her room. When Mrs. Dalton give away after smelling the wine that came from the mouth of Mary; Bigger thinks now about Mary. He finds her dead. He realizes what he has done due to fear. The problem is not solved by his act in fear, but it is intensified more than before. Now he worries how to dispose the dead body, otherwise, he would be convicted not only as a murderer but also the rapist which is considered as the most serious crime. He thinks of putting her body in a trunk and dispose it somewhere. He decides to tell lie that Mary is out as she wanted to go to Detroit. He would tell that she was with her friend Jan, a red communist. When Bigger takes the trunk to the basement, the idea comes to his mind that he can dispose the body in the furnace very easily. He cannot push her body fully into the furnace; the head is out. It makes the problem more complex, and in its fear and fury Bigger finds a way, it doesn't matter how it is cruel then, to cut the head off and thrust it also into the furnace. Bigger is sweating a lot, because he is aware of what he has done.

While committing this madly act, the cat come and sit on the trunk looking at the scene. Bigger feels of her as a witness to the crime. He tries to catch the cat with the thought of thrusting it also into the furnace, to destroy the witness also.

For some days Bigger succeeds to conceal his crime, but it is exposed by the investigators. Meanwhile Bigger want to take help of Bessie, a black girlfriend, in extorting money from the Daltons by telling lie that they have kidnapped their daughter. As Bessie denies to accomplice with him, he kills her also, fearing that Bessie may confess the truth about his deed if she is tortured with the intention. Thus, Bigger is not a willing murderer. He accidentally kills the first (white girl) and intentionally kills the second (black girl) due to same reason - he does not want to be convicted as a rapist and murderer, for which, he knows, he would be lynched brutally. But, ironically, he is convicted for the same. Ralph Ellison Advocates in his review of Native Son: 'Some reviewers are calling Bigger Thomas a neurotic, but it is a mistake to dismiss him as such. He is not crazy, he is the product of the restrictions placed upon 15,000,000 American citizens,....' (Ellison, 44).

In Lawd Today, Jake's character is shown as protesting one. He retorts to the white inspector who vexes him, saying that Jake does not do his work properly. But Jake fears that his manners may cause him to be fired from the job. He is unable to know what way he can overcome the approach of the inspector. Finally, his mind is occupied with the thoughts of war in which he daydreams of the black troop attacking the white. Practically he fears to do anything against the inspector, but the violence smoulders at least in his mind. 
There is an example of a black woman tortured cruelly by husband. Jake's wife bears it to the limit as an animal fearfully and helplessly suffers from the cruelty of a man. Jake drinks heavily and beats his wife inhumanly. She tries to teach him, but he neither love nor respect her. Being fearful of his violent state of mind, she pleads him "Don't beat me! Don't beat me, Jake!" (Lawd, 218). He stumbles on the floor, as she gives a lunge. He takes it as a reaction to his domination. She escapes when he tries to grab her with an intention of killing her. The fear that he may kill her, finally makes her react. She has to strike him to save herself. She strikes him with a piece of window glass. The violence and the life of Jake has been ended with that strike, but she is not calmed by that. When she realizes what she has done, she repents, “Lawd, I wish I was dead," (Lawd, 219).

In Big Boy Leaves Home, the protagonist rejects to do the things which are banned to the blacks. His friends insist on him to go to the swimming hole of a white man. He is lured to go there when all of his friends start towards it. He prefers to take risk for he does not want to be without the company of his friends. Before diving into the swimming hole they hesitate, but forget the danger while enjoying the swimming. They have a fix idea that if the white owner of the well comes there they would simply run away from him.

When a white woman comes to the hole, the black boys cannot decide what to do. Standing before her, they put their hands at their groins. The woman stands at the very place where they have kept their clothes. They argue among themselves if they should wait for the woman go away or if they should take their clothes and run fast. The woman is frightened at seeing the boys naked. She does not understand that she should simply go away from their way. Fearing that they may be caught in that accusable condition, two boys of them start towards her for their clothes. She is frightened more seeing them coming towards her. She screams so loudly that the white man, being nearby, misunderstands that the blacks have advanced towards her with an intention. He shots at Lester and Buck. Seeing them dying, Big Boy and Bobo are alarmed. The white man points his gun at Bobo. Running away, Bobo pleads: "Don shoot me, Mistah, don shoot me..." (Big Boy, 251) The two of them were shot and killed by the white man. To save Bobo, Big Boy clings at the rifle of the man. Both the boys fight back with the man. In the fight, the man drops the gun and Big Boy takes hold of it. The man demands for it, but Big Boy knows that the man is not going to spare them. He desperately shoots the white man. The black boys do not want the fight, but the white man shoots the two boys as one hunts the animals. Big Boy shoots the white man in order to save himself and his friend. Jeffrey D. Parker aptly says: 'It is the element of chance, of arbitrariness, of a meaningless and insignificant encounter fueled by racial prejudice and fear that becomes magnified to such a level of violence.' (Encyclopedia.com). But when the man is dead, Big Boy worries greatly about the result of it.

Bobo is terrified with the thought that the whites would lynch them for doing a serious crime like killing a white man. Big Boy hopes that his parents can do something to save him. When his parents come to know what has happened, they also worry deeply. His mother hopelessly says: "Ah done done all Ah kin fer yuh, Big Boy. Only Gawd kin hep yuh now." (Big Boy, 255). His father is unable to say how to save his son in that condition, but the first thought 
that comes to his mind is to keep a shotgun at hand. Big Boy is also fascinated by looking at the gun which is laid in a corner. The gun would be a means to save oneself when there is no better way left than this. When the door is knocked, Big Boy's father backs in fear but he moves towards the shotgun.

Big Boy's parent decide to send him away to Chicago stealthily. They make a secret plan to hide Big Boy in a deep pit at the hills until he gets the chance to catch a truck to go away. When he starts towards the kiln, he reminds of the wild hound which may kill and eat him. He feels the urge that he should go and take the shotgun back with which he can keep away the hounds and even the white people who are hunting him. He would not spare the hunters, but he fears that he may be exposed while on the way to the home. He hopes that Bobo would take a gun.

Big Boy selects the most safe pit at the hill. He could see into it nothing but darkness. A snake slides out of the pit. He kills the snake with a tree limb. He fears that there may be more snakes in the pit. It is dangerous to enter the pit but he feels that the snakes in the pit are not more dangerous than the whites who would lynch him, finding him out there. He warily enters the pit. Very soon, he is accustomed to the probable danger the of whites that is seeking him out.

Big Boy fears that white mob would find him in the pit. He regrets for not taking the gun from the house. He imagines if he had a gun, he would have kill even a mob with that. He imagines of killing the whites even without the gun if they come one by one. He imagines of catching the whites by their necks till they choke, and stomping at them as he did to the snake. For his good fortune he is not found by the whites, but a dog finds him and starts barking at the mouth of the hole. Big Boy is threatened that the dog may expose him to the whites. The fears of the furious dog and firmly sticks to the bottom of the hole. The dog advances towards him. Now, having no space to move back, Big Boy unknowingly catches at the dog. Wright describes how Big Boy kills the dog in a mix of fear and violence: "With strength flowing from fear, he closed his fingers, pushing his full weight on the dog's throat. The dog heaved again and lay still..." (Big Boy, 273). He fights with the dog and finally takes hold of its neck with the purpose to choke it.

\section{Conclusion}

The protagonists in the works of Richard Wright are not murderers by nature but the killers driven by fear. As Scott Bonn, a criminology professor, opines in his article: 'However, based on my experience as a criminologist, I have concluded that anger is not a primary emotion. Anger is a secondary emotion or reaction. I believe that fear is actually the root of all anger.' ( psychologytoday.com). They even repent what they have done, but much has been lost till then. The protagonists can never think of killing a white person, but, at the same time, they do not yield before the white in an extension that they would accept to be killed by the whites. They fear the whites may kill them. They react in some way to save themselves which, occasionally, turns into violence so that they kill the whites, though unwillingly. 


\section{Works Cited:}

1) Richard Wright., Native Son. Vintage Books, London, 2000. p. 117.

2) Richard Wright, "Lawd Today!" in ...... Richard Wright: Early Works. Library of America, USA. 1984. p. 218.

....p. 219.

3) Richard Wright, "Big Boy Leaves Home?", in ..... Richard Wright: Early Works. Library of America, USA. 1984. p. 251.

.... p. 255.

.... p. 273.

4) Ralph Ellison, 'Book Reviews: Native Son, by Richard Wright'. Kinnamon Keneth, (ed.), Critical essays on Richard Wright's Native son, Twayne Publishers, New York, 1997. p. 44. https://archive.org/details/criticalessayson0000unse_y6e6/mode/2up?q=Richard+Wright\%5C $\% 27 \mathrm{~s}+$ Native+Son

5) 'Big Boy Leaves Home by Richard Wright, 1938', Reference Guide to Short Fiction, Encyclopedia.com. Web. 24 Jan. 2022 <https://www.encyclopedia.com>.

https://www.encyclopedia.com/arts/encyclopedias-almanacs-transcripts-and-maps/big-boy$\underline{\text { leaves-home-richard-wright-1938 }}$

6) Bonn Scott, 'Fear-Based Anger Is the Primary Motive for Violence', Posted July 17, 2017 https://www.psychologytoday.com/us/blog/wicked-deeds/201707/fear-based-anger-is-theprimary-motive-violence 